\title{
Quantification of Storm-Induced Bathymetric Change in a Back-Barrier Estuary
}

\author{
Neil K. Ganju ${ }^{1}$ - Steven E. Suttles ${ }^{1}$ - Alexis Beudin ${ }^{1}$ • Daniel J. Nowacki ${ }^{1}$ • \\ Jennifer L. Miselis ${ }^{2}$ • Brian D. Andrews ${ }^{1}$
}

Received: 1 April 2016 /Revised: 13 July 2016 / Accepted: 16 July 2016 / Published online: 26 July 2016

(C) The Author(s) 2016. This article is published with open access at Springerlink.com

\begin{abstract}
Geomorphology is a fundamental control on ecological and economic function of estuaries. However, relative to open coasts, there has been little quantification of storminduced bathymetric change in back-barrier estuaries. Vesselbased and airborne bathymetric mapping can cover large areas quickly, but change detection is difficult because measurement errors can be larger than the actual changes over the storm timescale. We quantified storm-induced bathymetric changes at several locations in Chincoteague Bay, Maryland/ Virginia, over the August 2014 to July 2015 period using fixed, downward-looking altimeters and numerical modeling. At sand-dominated shoal sites, measurements showed storminduced changes on the order of $5 \mathrm{~cm}$, with variability related to stress magnitude and wind direction. Numerical modeling indicates that the predominantly northeasterly wind direction in the fall and winter promotes southwest-directed sediment transport, causing erosion of the northern face of sandy shoals; southwesterly winds in the spring and summer lead to the opposite trend. Our results suggest that storm-induced estuarine bathymetric change magnitudes are often smaller than those detectable with methods such as LiDAR. More precise fixed-sensor methods have the ability to elucidate the geomorphic processes responsible for modulating estuarine bathymetry on the event and seasonal timescale, but are limited spatially. Numerical modeling enables interpretation of broad-
\end{abstract}

Communicated by Carl T. Friedrichs

Neil K. Ganju

nganju@usgs.gov

1 US Geological Survey, Woods Hole Coastal and Marine Science Center, Woods Hole, MA, USA

2 US Geological Survey, St. Petersburg Coastal and Marine Science Center, St. Petersburg, FL, USA scale geomorphic processes and can be used to infer the long-term trajectory of estuarine bathymetric change due to episodic events, when informed by fixed-sensor methods.

Keywords Bathymetric change - Sediment transport . Numerical modeling $\cdot$ Back-barrier estuary

\section{Introduction}

The morphology of an estuary is a primary control on circulation (Ralston et al. 2010; Defne and Ganju 2015), wave propagation (Olabarrieta et al. 2011), ecosystem function (Lopez et al. 2006), and water quality (Chubarenko and Tchepikova 2001). Understanding potential changes to geomorphology due to storm events, sea level rise, and anthropogenic influence enables estimating changes to the physical and ecological function of estuaries. Historically, bathymetric surveys of inlets and estuaries were performed using lead line soundings and, more recently, vessel-mounted single-beam acoustic sounding devices. Modern efforts to estimate bathymetric change rely on digitizing these historical records to a common horizontal and vertical datum and differencing depth measurements to derive change magnitudes (Van der Wal and Pye 2003; Jaffe et al. 2007). These methods have proved invaluable for detecting and modeling multidecadal changes under large external forcings (Ganju et al. 2009; van der Wegen et al. 2011), but are limited at finer spatial and temporal scales. Modern methods, such as swath bathymetry and airborne LiDAR are capable of capturing a large spatial footprint quickly and are more accurate compared to historical methods. Nonetheless, the accuracy of all these modern methods is hampered by errors including instrument position (e.g., heading, attitude, heave, velocity) and bottom type and for boat-based operations, speed-of-sound estimation, and 
water level changes. Ultimately, these systematic errors can exceed $+/-10 \mathrm{~cm}$ (Hilldale and Raff 2008; Bailly et al. 2010). Errors of this magnitude limit the ability to estimate real changes in bathymetry that are less than $20 \mathrm{~cm}$. Acoustic methods using submerged, fixed instruments have proven accurate for detecting changes over short timescales and the associated sediment transport mechanisms (Jestin et al. 1998; Bassoullet et al. 2000; Traykovski et al. 2004) but are spatially limited. It is not clear what methods, and at what scale and resolution, are necessary for understanding storminduced bathymetric changes in estuaries.

In this study, we present bathymetric change results from bed-mounted acoustic altimeters in Chincoteague Bay, Maryland/Virginia, a back-barrier lagoon on the midAtlantic coast of the USA (Fig. 1). We apply a coupled ocean-wave-sediment transport model to interpret the results and understand the long-term trajectory of estuarine morphology under episodic storm forcing. We note that measured and modeled changes are smaller than errors associated with the aforementioned change detection methods, indicating that seasonal storm-induced changes are not easily resolved with such methods. We discuss timescales of bathymetric change and interactions of sediment transport with vegetation, as well as the limitations of models in representing these processes. Lastly, we address the overall resilience of estuaries from a geomorphic perspective.

\section{Site Description}

Chincoteague Bay is a back-barrier estuary behind Assateague Island, on the Maryland/Virginia Atlantic coast (Fig. 1). The estuary spans approximately $60 \mathrm{~km}$ from Ocean City Inlet at the north to Chincoteague Inlet in the south; maximum width is $8 \mathrm{~km}$ near the middle of the estuary. Mean depth is approximately $1.6 \mathrm{~m}$, with maximum depths exceeding $5 \mathrm{~m}$ in the inlets. Typical channel depths within the estuary are approximately $3 \mathrm{~m}$. The eastern, back-barrier side of the bay is characterized by numerous shoals formed through inlet formation and overwash processes (Bartberger 1976; Seminack and Buynevich 2013) and seagrass meadows while the western side is deeper with no noticeable shoals. The entire bay is fringed in most areas by salt marsh with some shoreline hardening on the west side of the bay.

Tide range approaches $1 \mathrm{~m}$ in the adjacent coastal ocean, but is attenuated rapidly through the inlets; water levels in the
Fig. 1 Site map with insets for northern and southern shoals. Altimeters were deployed at paired sites CB04/CB05 and CB07/CB08; hydrodynamic equipment deployed at sites $\mathrm{CB} 03, \mathrm{CB} 06$, and $\mathrm{CB} 07$. White dashed boxes indicate coverage area for Figs. 10, 11, and 13. White bars in insets indicate search radius for optimal site in model assessment

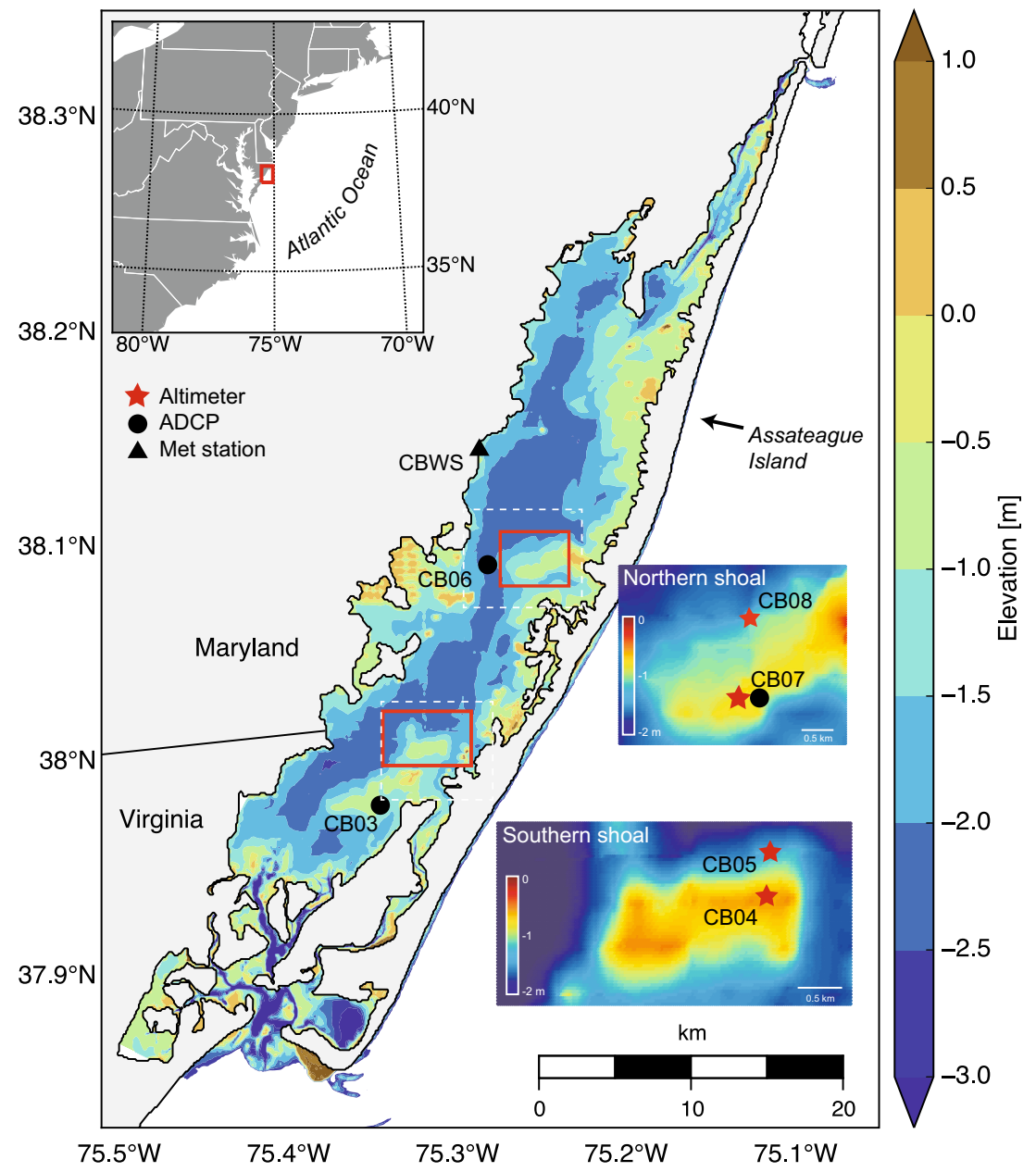


middle of the bay are dominated by subtidal processes such as wind setup and oceanic forcing with a tidal range of less than $0.1 \mathrm{~m}$ (Pritchard 1960). River input is minimal with the highest discharge and lowest salinities near the northwest part of the bay. Groundwater discharge to the Maryland coastal bays, including the northern end of Chincoteague Bay, is estimated at $0.5 \mathrm{~m}^{3} / \mathrm{s}$ (Dillow and Greene 1999). Atmospheric forcing is characterized by episodic frontal passages in winter, bringing strong northeast winds; summer and fall are characterized by gentler southwest winds. Waves within the bay are predominantly locally generated, with substantial dependence on wind direction and fetch due to the alignment of the estuary along a southwest to northeast axis.

Bartberger (1976) detailed sources and magnitudes of sediment delivery to Chincoteague Bay, indicating that storm overwash is the principal source of sand to the estuary. Shoreline erosion, primarily on the western edge of the bay, supplies much of the fine sediment deposited in the main basin. The presence of historical inlets along the current barrier island (Seminack and Buynevich 2009) suggests the development of relict flood-tidal shoals on the eastern side of the bay. The modern grain-size distribution consists of fine to coarse sand near the inlets and along the eastern side of the bay, with mud dominating the western side of the bay (Wells et al. 1997, 1998). In this study, we report bathymetric changes from four sites on two sand-dominated shoals (CB04, CB05, CB07, CB08; Fig. 1).

\section{Methods}

\section{Field Observations}

Instrumentation was deployed from August 10, 2014, to July 12,2015 , in order to observe an entire year of forcing conditions (Table 1, Fig. 1). Instruments were recovered, downloaded, and serviced three times during that period (October 2014, January 2015, and April 2015). Site CB03 is within a seagrass meadow in the southern basin; sites CB04 and CB05 are on the crest and northern face, respectively, of a sandy shoal $5 \mathrm{~km}$ northeast of $\mathrm{CB} 03$ (hereafter the "southern shoal"). Site CB06 is within the main channel north of the nominal boundary between the northern and southern basins. Sites CB07 and CB08 are on the crest and northern face, respectively, of another shoal in the northern portion of the bay (hereafter the "northern shoal"). Site CBWS is a landbased meteorological station on the western shoreline collecting wind speed, direction, and other ancillary data.

\section{Hydrodynamics}

At sites CB03, CB06, and CB07, we deployed bed-mounted platforms with Nortek Aquadopp acoustic Doppler current profilers (ADCPs) measuring water velocity; directional waves were measured at $\mathrm{CB} 06$ and $\mathrm{CB} 07$ with ADCPs, and non-directional waves were measured at $\mathrm{CB} 03$ using $\mathrm{RBR}$ $\mathrm{D} \mid$ Wave pressure sensors. All sensors were approximately $0.15 \mathrm{~m}$ above bottom. Estimates of directional wave energy spectra were made using atmospherically corrected pressure and three-beam velocities from the ADCPs as input into the DIWASP software package (Johnson 2002; Dusek 2011). The ADCPs collected wave bursts of 1024 samples of pressure and radial beam velocities measured at a $2-\mathrm{Hz}$ sampling rate with a burst interval of $30 \mathrm{~min}$. Wave burst velocity bin sizes for 1and 2-MHz Aquadopps were 1 and $0.5 \mathrm{~m}$, respectively, centered at distances of 1.37 and $0.64 \mathrm{~m}$, respectively, from the instrument transducers. Mean current interaction was accounted for by Doppler shifting wave numbers following Jones and Monismith (2007). Non-directional waves were sampled at $6 \mathrm{~Hz}$ (4096 samples every $30 \mathrm{~min}$ ). Wave statistics calculated from the spectra and used for stress calculations are significant wave height, peak period, and mean wave direction. Current velocity and direction from the near-bottom bin and bulk wave statistics (peak period, significant wave height, wave direction) were used to calculate combined wavecurrent shear stresses following Madsen (1994); for the following analyses, the direction of stress was assigned as the velocity direction. The $\mathrm{ADCP}$ at site $\mathrm{CB} 07$ was removed during the April servicing.

\section{Bed Elevation}

We deployed two pairs of acoustic altimeters (Echologger AA400, $450 \mathrm{kHz}$, resolution $1 \mathrm{~mm}$ ) on the two shoals over the August 10, 2014, to July 10, 2015, period (sites CB04, $\mathrm{CB} 05, \mathrm{CB} 07, \mathrm{CB} 08)$. The altimeters were mounted looking downward from the center of a two-post frame composed of a 2-in.-diameter aluminum pipe (Fig. 2). The posts were driven into the seabed to a depth of approximately $1.5 \mathrm{~m}$. All altimeters began with an initial distance to seabed between 0.4 and $0.5 \mathrm{~m}$; actual distances were confirmed with manual meterstick measurements by divers in addition to the instrument measurement itself. We detected no vertical movement of the frames using RTK-GPS measurements during two successive servicing trips; scour or deposition under the frames was minimal as confirmed by diver observation and time-lapse underwater photography. Measurements were corrected for changes in the speed of sound (default value of $1500 \mathrm{~m} / \mathrm{s}$ ) using the instrument-reported temperature (temperature decreases in winter would tend to over-report distances due to a decrease in the speed of sound). The altimeters collected 10 samples at $1 \mathrm{~Hz}$ every $15 \mathrm{~min}$; these were averaged with outliers removed from the time-series using a medianfiltering method. Altimeters were serviced on three occasions during the deployment and returned to the fixed frame, in approximately the same vertical location within the mounting 
Table 1 Deployment locations, instrumentation, and surficial sediment type

\begin{tabular}{|c|c|c|c|c|c|c|}
\hline Site & Type & Depth (m) & Latitude & Longitude & Instruments & Bed type $\left(\mathrm{D}_{50}, \%\right.$ fines $)$ \\
\hline CB03 & Seagrass meadow & 1.5 & 37.9749 & -75.34500 & $1 \mathrm{MHz}$ Nortek Aquadopp HR, RBR D|wave & Mixed ( $68 \mu \mathrm{m}, 45 \%$ fines $)$ \\
\hline CB04 & Southern shoal & 0.75 & 38.01002 & -75.30959 & Echologger AA400 & Sand ( $164 \mu \mathrm{m}, 6 \%$ fines $)$ \\
\hline CB05 & Southern shoal & 1.3 & 38.01175 & -75.30809 & Echologger AA400 & Sand $(149 \mu \mathrm{m}, 7 \%$ fines $)$ \\
\hline CB06 & Channel & 2.5 & 38.0913 & -75.2831 & $1 \mathrm{MHz}$ Nortek Aquadopp w/waves & Mud (12 $\mu \mathrm{m}, 67 \%$ fines $)$ \\
\hline CB07 & Northern shoal & 1.0 & 38.09011 & -75.25226 & Echologger AA400, 2 MHz Nortek Aquadopp & Sand $(104 \mu \mathrm{m}, 11 \%$ fines $)$ \\
\hline CB08 & Northern shoal & 1.2 & 38.0983 & -75.2500 & Echologger AA400 & Sand $(171 \mu \mathrm{m}, 2 \%$ fines $)$ \\
\hline CBWS & Land & - & 38.14824 & -75.28625 & Onset $\mathrm{HOBO}$ weather station & - \\
\hline
\end{tabular}

Additional details available from Suttles et al. (2016)

bracket; during data processing, we assumed no change in seabed elevation while the instrument was removed (i.e., the first post-servicing distance measurement was shifted to match the last pre-servicing distance measurement; average out-of-water interval was 4 day). All of the frames were impacted by ice formation in February 2015; one frame (CB05) remained in position, though the altimeter data appeared corrupted during ice cover periods (as determined by air/ water temperature), possibly due to attached ice lifting the frame when water level rose. We compensated for this adjustment at site $\mathrm{CB} 05$ by shifting the first post-ice distance measurement to match the last pre-ice distance measurement.

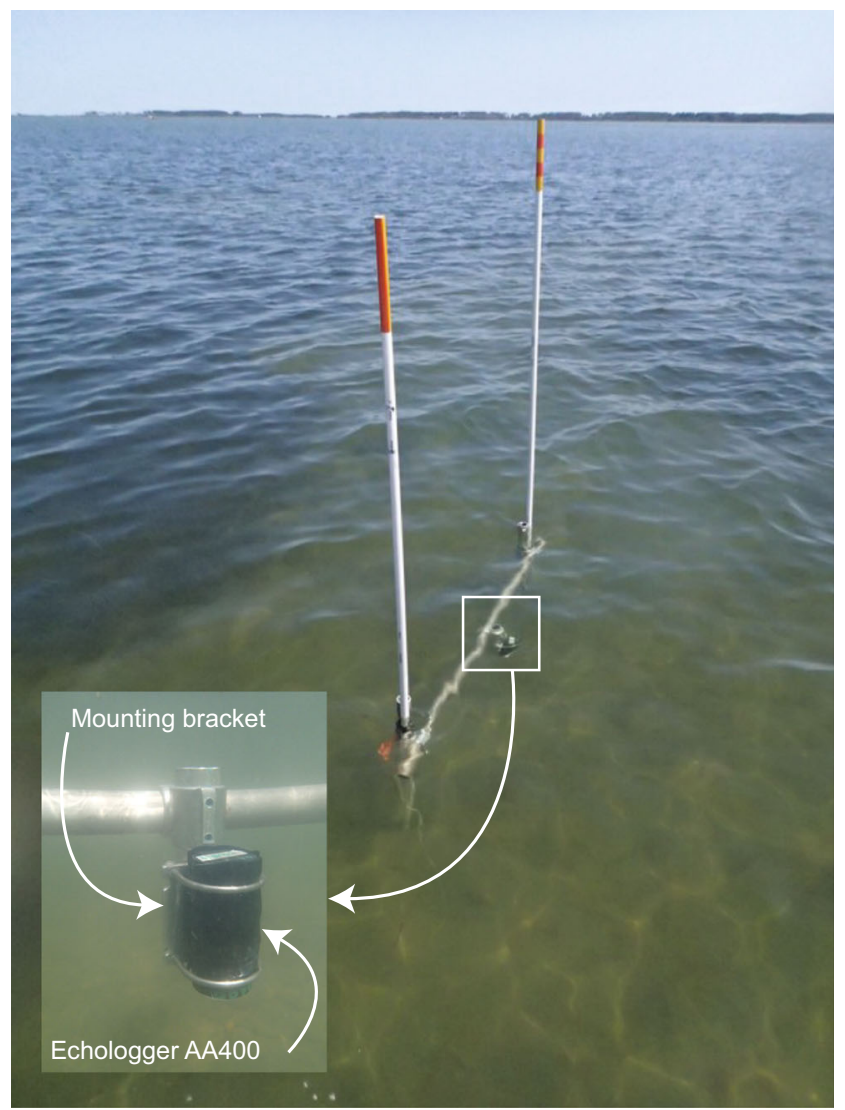

Fig. 2 Altimeter frame and altimeter as deployed at CB04
After frame disruption from ice formation, site CB08 was redeployed in April, and the distance measurement was reset to an arbitrary value due to a lack of a vertical datum during the first deployment. Sites CB04 and CB07 were not redeployed.

\section{Numerical Modeling}

We applied a coupled hydrodynamic, wave, and sediment transport model of Chincoteague Bay to constrain and understand the sediment transport regime and bathymetric change observations from the altimeter sites. The model domain includes all of Chincoteague Bay, the two inlets, and the barrier island and extends offshore approximately $15 \mathrm{~km}$ to capture oceanic influence. The model was developed using the COAWST framework (Warner et al. 2010) which couples ROMS (ocean), SWAN (wave), and the CSTMS (sediment) models. Atmospheric forcing including wind speed and direction, barometric pressure, and solar radiation were obtained from the NCEP/NAM model (NOAA 2016), whereas offshore subtidal (low-frequency) water levels, depth-averaged currents, temperature, and salinity were extracted from the US East Coast forecast model (Warner et al. 2010). Tidal forcing on the boundary was specified using the main tidal constituents $\left(\mathrm{K}_{1}, \mathrm{O}_{1}, \mathrm{M}_{2}, \mathrm{~N}_{2}\right.$, and $\left.\mathrm{S}_{2}\right)$ from the ADCIRC database (Mukai et al. 2002). The horizontal grid resolution was approximately $100 \mathrm{~m}$, with seven equally spaced vertical sigma layers. Activated options include wetting and drying of intertidal areas, wave-current interaction in the bottom boundary layer (Madsen 1994), bedload (Soulsby and Damgaard 2005), erosion via the excess shear stress formulation (Ariathurai and Arulanandan 1978), and specification of active layer thickness (Harris and Wiberg 1997). Suspended sediment and tracer transport are calculated using user-specified advection schemes.

The bottom elevation was initialized from a collection of the most recent topo-bathymetry data available (USGS 2015; USACE 2013; Wells et al. 2004). The bed sediment distribution was initialized using grain-size data collected by Wells et al. (1997, 1998) between 1991 and 1997 in Maryland and 
2006-2007 in Virginia (Fig. 3). Three sediment classes were specified within the bay, representing fine silt $\left(\tau_{c}=0.09 \mathrm{~Pa}\right)$, coarse silt $\left(\tau_{c}=0.12 \mathrm{~Pa}\right)$, and fine sand $\left(\tau_{c}=0.17 \mathrm{~Pa}\right)$. One bed layer was implemented, with a uniform porosity of 0.5 . At the shoal sites, the fine sand class was dominant representing $>75 \%$ of the bed mass. At the channel site, the bed was a mix of sand, silt, and clay (i.e., mud). All sediment classes were treated as unflocculated and were modeled independently. More details on this implementation can be found in Warner et al. (2008). To capture the influence of the most energetic storms while all sensors were functioning, we simulated the November 1, 2014, to March 1, 2015, period. Model assessment was performed using the Brier skill score (BSS; Brier 1950) and the related coefficient of determination $\left(r^{2}\right)$. We refrained from parameter tuning in order to isolate the general behavior of the sediment transport model in response to storm forcing and identify the unaltered skill of the model (Ganju et al. 2015).

\section{Results}

\section{Hydrodynamics}

Observed water levels at all sites tracked closely and were primarily forced by meteorological events characterized by excursions greater than $0.5 \mathrm{~m}$, with a smaller contribution from tidal forcing (<0.2-m range; Fig. 4). Depth-averaged tidal currents on the shoals (CB03, CB07) were typically less than $0.3 \mathrm{~m} / \mathrm{s}$. Current magnitudes at site CB03 appear to increase during the winter, perhaps due to senescence of seagrass meadows (Hansen and Reidenbach 2013). Wave heights exceeded $0.5 \mathrm{~m}$ during a storm event on December 7,2014 , reaching over $40 \%$ of the water depth on one occasion; peak wave periods reached $3 \mathrm{~s}$. At the shoal sites, due to relatively weak currents, mean wave-induced stresses accounted for $\sim 70 \%$ of the total estimated mean bed shear stress; wave and current-induced stresses were approximately equivalent at channel site CB06. Stresses from tidal currents alone (95th percentile $<0.11 \mathrm{~Pa}$ at sites $\mathrm{CB} 03$ and CB06) were typically under the mobility threshold for the local sand (0.17 Pa for $180 \mu \mathrm{m}$ sand; Soulsby 1997), indicating that bed motion is only expected during episodic wave events.

Stress directions were assigned using the currents and accumulated to infer the net direction of transport (Figs. 5 and 6). Given the directional coherence among wind, waves, and currents at shoal sites (see below), this is an appropriate assumption. Sites CB03 and CB07 showed a dominant northeast-tosouthwest stress direction, in accordance with the dominant wind direction in fall and winter (Fig. 7); stresses at site CB03 appeared to balance in spring, likely due to increased attenuation by renewed seagrass meadows and southwest winds in spring-summer which likely have more influence in the southern basin. Site CB06 (Fig. 6) demonstrated the opposite cumulative stress direction, in accordance with an upwinddirected channel flow (Csanady 1973): a northeast-directed stress when winds originate from the northeast, and viceversa when winds originate from the southwest. It is noted that stresses at site $\mathrm{CB} 03$ are likely not representative of stresses at sites $\mathrm{CB} 04 / \mathrm{CB} 05$, but we present them to demonstrate the persistent southwest-directed stresses on the shallows of the southern portion of the bay.

\section{Bed Elevation}

The southern shoal sites (CB04, CB05) showed a general deepening of the bed from August to February, punctuated by episodic shoaling and deepening (Fig. 5). The largest episodic changes during this period were associated with discrete stress maxima corresponding to wind events. Both sites were impacted by ice in late February, and site CB04 was discontinued due to frame disruption; site CB05 was redeployed and showed relatively stable bathymetry until July. The northern shoal sites (CB07, CB08) also showed a general deepening trend (Fig. 6), and site CB08 experienced the largest episodic changes of all the sites (December 7, 2014; February 10, 2015) associated with storm passage. Again, sites were impacted by ice, and in this case both frames at
Fig. 3 Surficial sediment distribution by mass in Chincoteague Bay, as implemented in the COAWST model (Wells et al. 1997, 1998). Model domain extends offshore approximately $15 \mathrm{~km}$

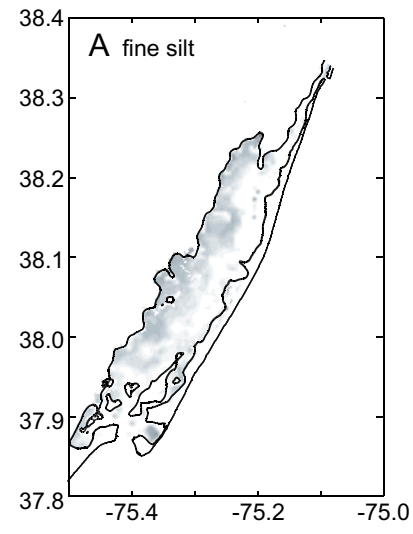

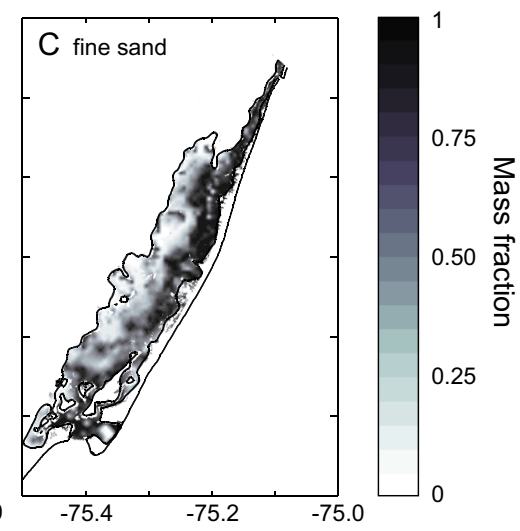


Fig. 4 Time-series of a wind speed and direction at CBWS, $\mathbf{b}$ de-meaned water level at CB06, c depth-averaged velocity, $\mathbf{d}$ significant wave height, and e combined wave-current bed stress at sites CB03 and CB07. Northsouth components of wind speed are exaggerated by a nominal value relative to east-west components for clarity
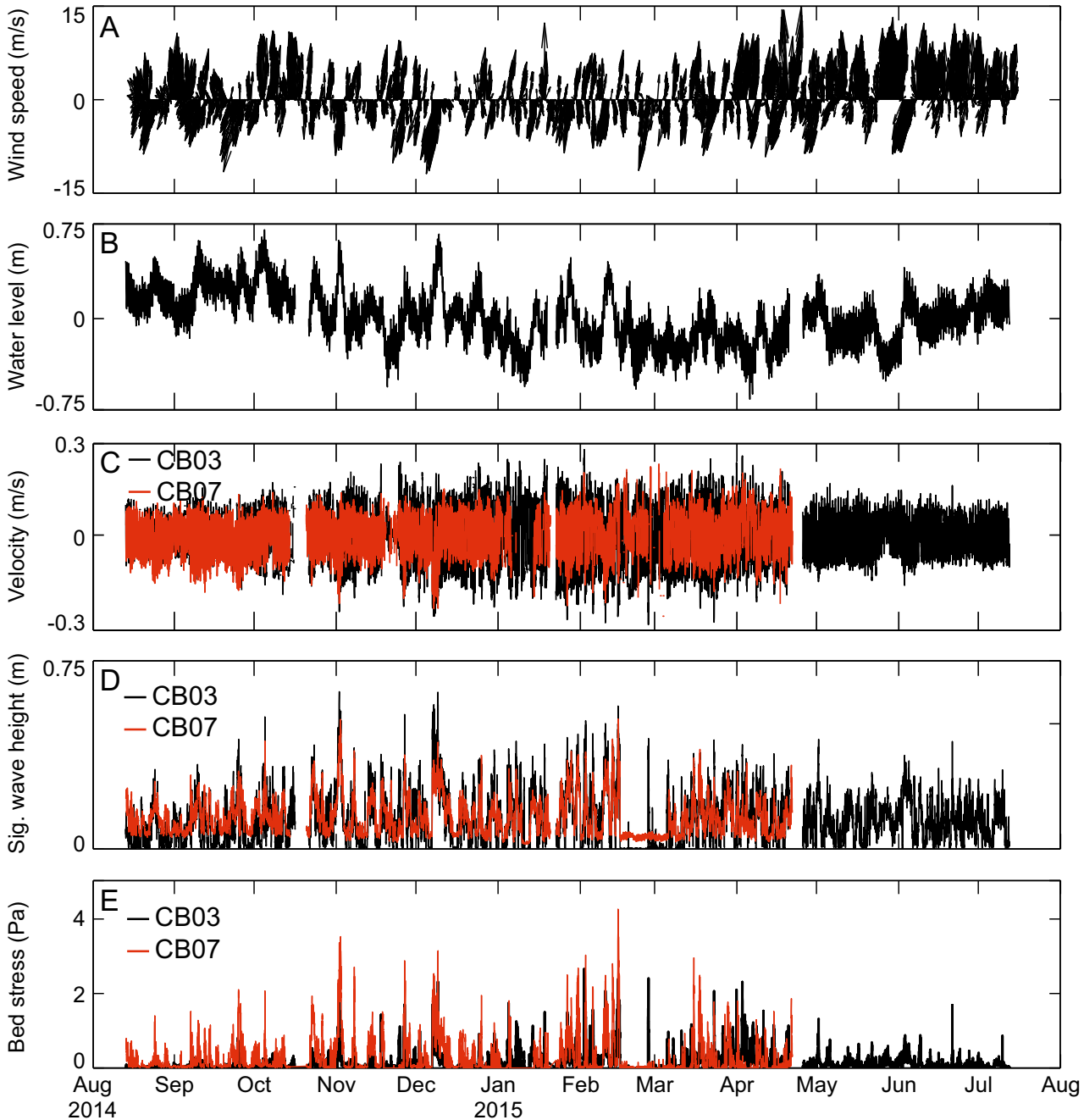

the northern shoal were damaged. Upon redeployment in April 2015, site CB08 showed some episodic changes with a small overall trend. The largest single excursion from all four sites was $<10 \mathrm{~cm}$, over the course of a single winter storm. The apparent seasonal variability was between 4 and $11 \mathrm{~cm}$, though the removal and redeployment of CB08 prevented a continuous vertical datum. We estimated the time of ice disturbance and noted the pre-ice distance and shifted the ensuing
Fig. 5 Seabed elevation and directional combined wavecurrent bed shear stress from southern sites. Bed stress data is from site $\mathrm{CB} 03$, approximately $5 \mathrm{~km}$ from CB04 and CB05, and may not be representative of stresses on the southern shoal. Scale for cumulative stress not shown
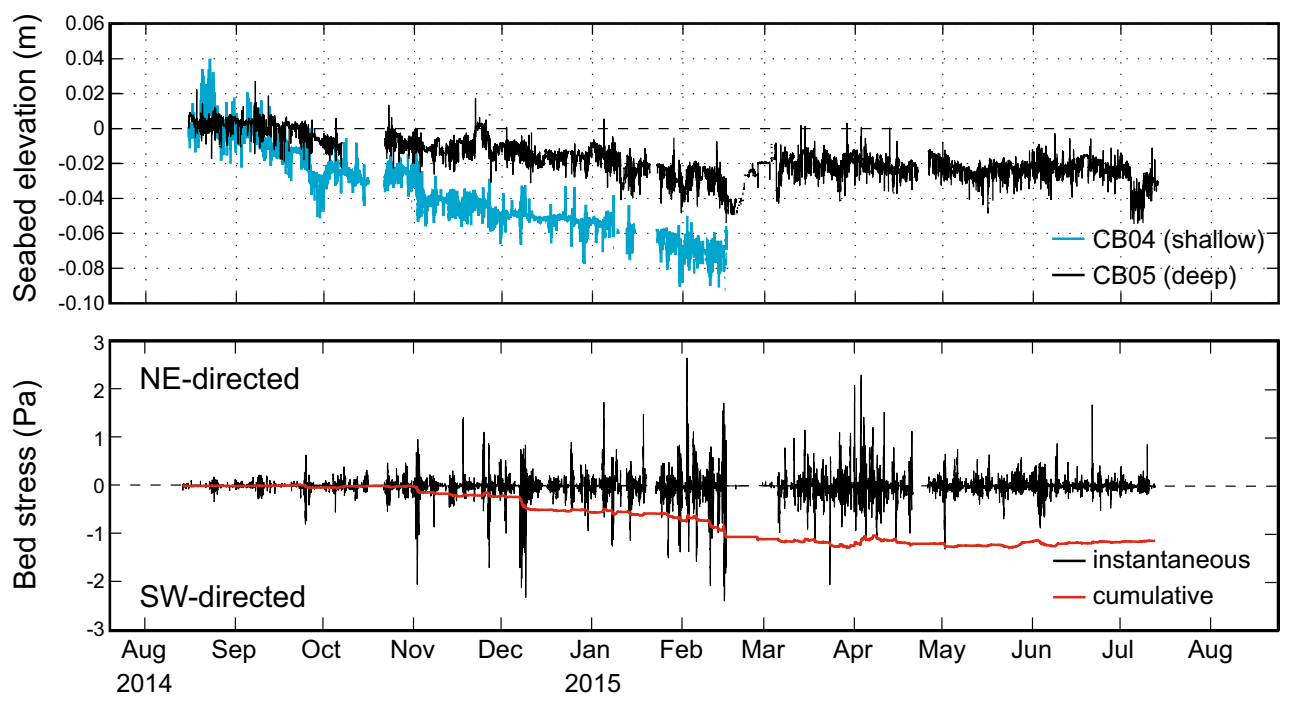
Fig. 6 Seabed elevation and directional combined wavecurrent bed shear stress from northern shoal sites.

Instantaneous stress data are from site $\mathrm{CB} 07$; cumulative bed stress data from site $\mathrm{CB} 06$ represent conditions in the adjacent channel. Units of cumulative stress not shown
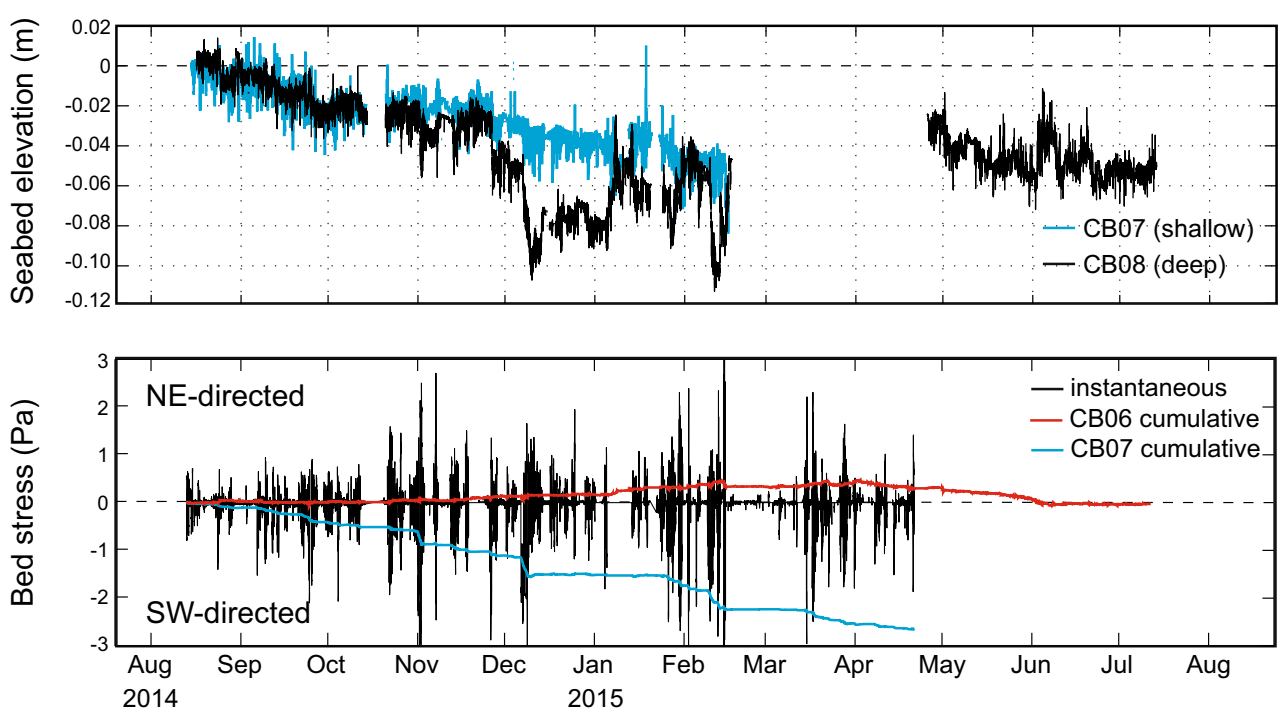

time-series (post-ice), to match this pre-ice distance. There is likely an error on the order of 1-2 cm from the uncertainty.

At site $\mathrm{CB} 08$, where the largest bed changes were observed, the deepening trend in winter is actually a series of episodic deepening events due to winter storms with northeasterly winds. Time-integrated excess shear stress (i.e., over a nominal movement threshold of $0.17 \mathrm{~Pa}$ for $180 \mu \mathrm{m}$ sand; Soulsby 1997) was positively correlated with maximum bed changes over 3-day intervals (Fig. 8). The overall deepening trend is likely due to the dominance of northeast wind events, southwest-directed near-bottom flow on the shoals, and resultant southwest-directed suspended and bedload transport during that period. This suggests either a local sediment flux divergence at our altimeter locations during the winter (leading to steepening of the shoal) or more regional sediment flux gradients resulting in complete displacement of the shoal feature to the southwest. Given the persistent location of the shoal over recent decades (see "Discussion"), it is likely the former. In the following sections, we use the hydrodynamic model to constrain the bed level measurements.

The apparent noise in the altimeter time-series is likely due to a combination of small bedforms, biological interference, and/or near-bed flocculated material. Estimation of ripple heights using collected wave data and median grain size (Traykovski 2007) indicates heights typically less than $1 \mathrm{~cm}$, though during large events predicted ripple heights exceed $5 \mathrm{~cm}$. Malarkey et al. (2015) suggest that small amounts of clay and biologically derived excretions, common in estuaries, inhibit ripple development, though transport can still occur. Therefore, it is not likely that the large changes in seabed elevation estimated by the altimeters are due to individual ripples migrating past the sensor. In any case, the similar
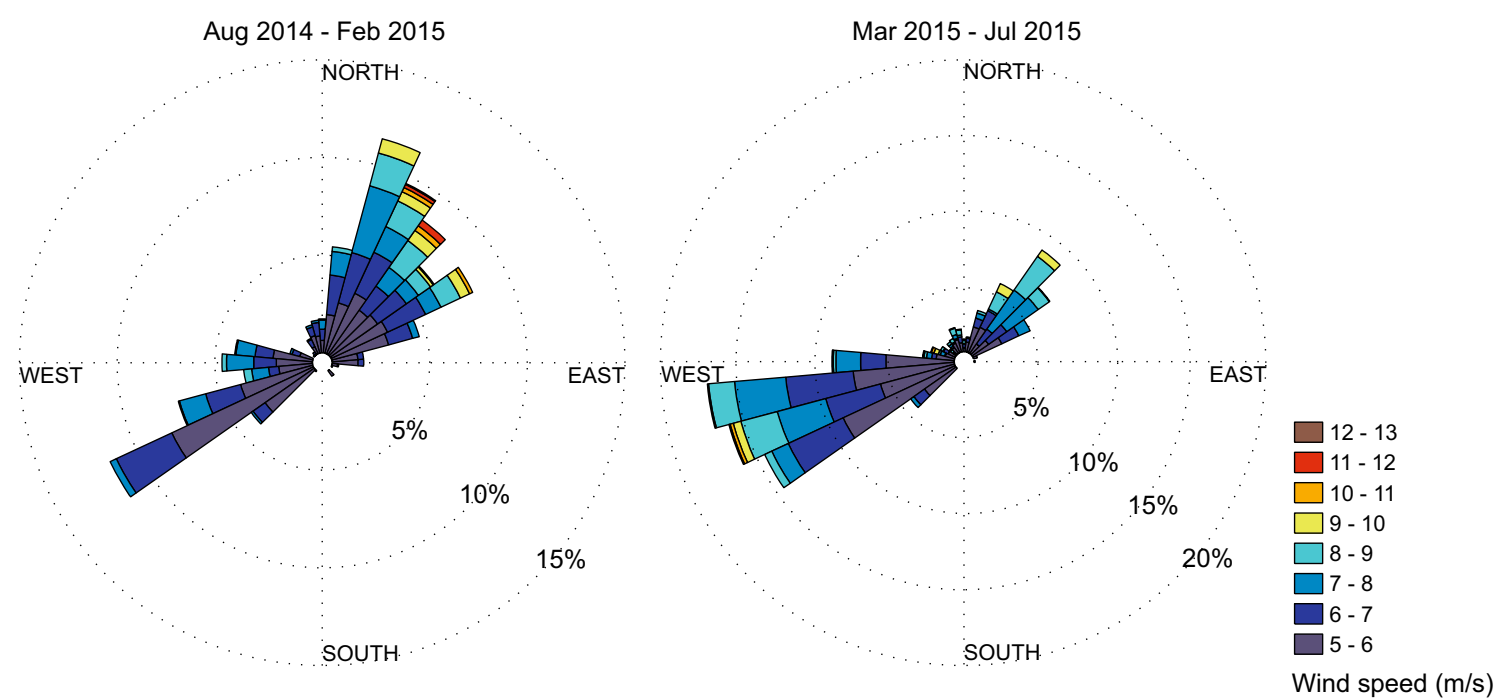

Fig. 7 Wind roses at site CBWS for winds exceeding $5 \mathrm{~m} / \mathrm{s}$. Fall and winter experience the strongest wind events from the northeast, while spring and summer experience the strongest winds from the southwest 


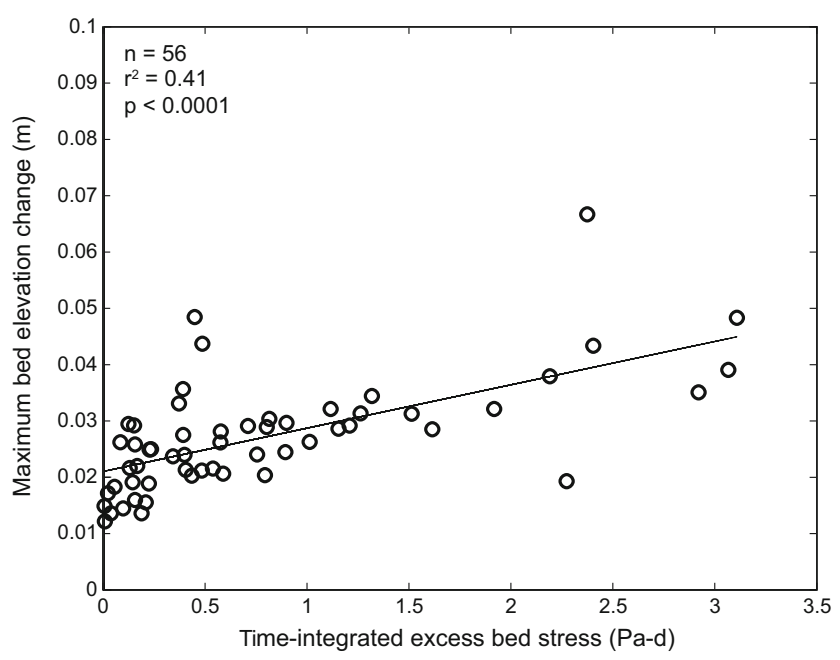

Fig. 8 Maximum bed elevation change over 3-day intervals as a function of time-integrated ( 3 days) excess shear stress $(>0.17 \mathrm{~Pa}$ ) at site CB08

seasonal and event response at the four sites indicates that the signal is likely not migration of individual ripples and is likely larger-scale transport across the shoals.

\section{Model Results and Comparisons with Observations}

With regard to overall trends, model skill for bed elevation is varied, with the best agreement at site $\mathrm{CB} 04$ and the worst agreement at CB05 (Fig. 9, Table 2). Although the model shows that CB04 is within an erosional area (for both sand and silt) on the northern face of the shoal, in agreement with observations, the model predicts that $\mathrm{CB} 05$ is located on the depositional side of a sharp erosion/deposition interface
(Fig. 10d, g). The observations indicate that both sites should experience similar amounts of erosion during this period. Similarly, modeled bed elevation at sites CB07 and CB08 changes minimally over the simulation; the model places both sites on erosion-deposition interfaces (Fig. 11d, g), though the patterns of sand and silt bed change are not congruent. Given the sharp gradients in sediment transport, we expanded the skill assessment to model cells within a 500-m radius ( $\sim 5$ grid cells) of the observation site (see scale on Fig. 1 insets). This increases agreement with observed changes substantially at all sites (Fig. 11, Table 2).

We assessed the model skill for episodic changes by linearly de-trending the observed and modeled bed elevation, to yield de-trended seabed elevation. Overall, model skill appears to decrease (Fig. 12, Table 2), though specific bed changes associated with storms are captured. For example, the strongest southwesterly wind event of the simulated period, on November 23, 2014, led to an observed and modeled increase in de-trended seabed elevation at all sites except CB08. The strongest northeasterly wind event, on December 7,2014 , led to a decrease in de-trended seabed elevation at all sites and was captured by the model. Again, we reassessed the model within a 500-m radius and found nearby increases in skill because of the sharp erosion-deposition interfaces in the model. Overall, the episodic changes simulated by the model are the same order of magnitude as measured changes $(<2 \mathrm{~cm})$, though the model underestimates elevation change during the largest events.

During two of the strongest episodic events, the model does approximate the deepening and shoaling characteristics, though the elevation change magnitude is
Fig. 9 Comparison of observational seabed elevation data and numerical model results. Optimal site refers to model grid cell within $500 \mathrm{~m}$ of the observational site with the highest skill score relative to observational data, to demonstrate spatial variability in skill
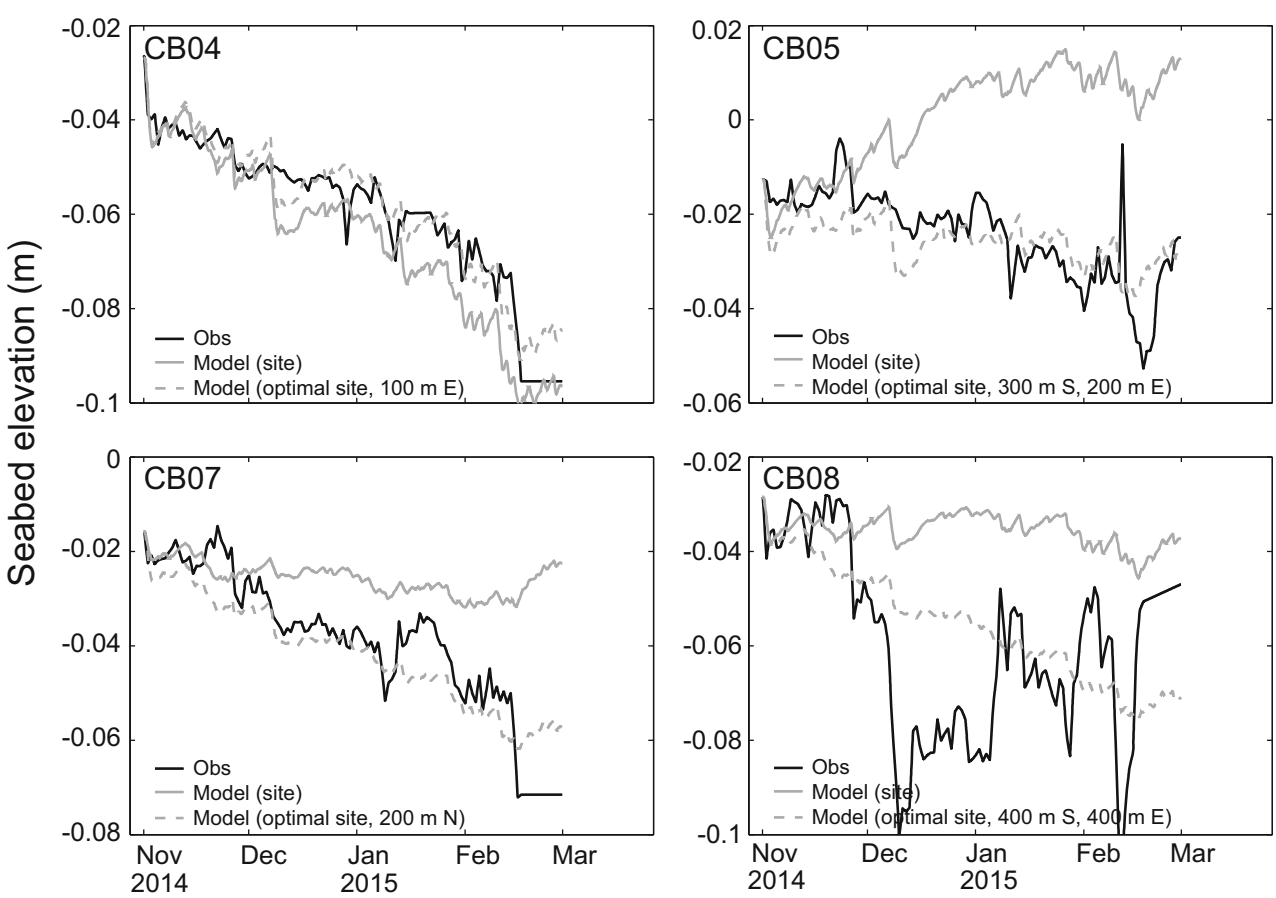
Table 2 Model skill assessment for bed elevation and linearly detrended bed elevation (second value in each entry)

\begin{tabular}{lllll}
\hline Site & $r^{2}$ & BSS & Optimal $r^{2}$ & Optimal BSS \\
\hline CB04 & $0.90,0.32$ & $0.72,0.28$ & $0.92,0.62$ & $0.90,0.50$ \\
CB05 & $-0.36,0.12$ & $-9.8,-0.20$ & $0.69,0.14$ & $0.38,0.10$ \\
CB07 & $0.25,-0.24$ & $-0.62,-0.54$ & $0.85,0.12$ & $0.77,0.12$ \\
CB08 & $0.00,-0.06$ & $-1.6,-0.10$ & $0.19,0.41$ & $0.11,0.30$ \\
\hline
\end{tabular}

Brier skill score (BSS) ranges from 1 to $-\infty$; a value greater than zero indicates a time-varying prediction that is better than the time-averaged mean value

underestimated. Average near-bed currents and combined suspended and bedload transport for sand and silt classes were computed over the entire simulation period and during two storm events (northeast wind event, December 79, 2014; southwest wind event, November 23-25, 2014). At the northern shoal (Fig. 11), the entire simulation indicates sand deposition at the base and crest of the shoal, with erosion across the northern face; silt deposition is focused between the 1- and 2-m contour, with erosion in the deeper channel. During the northeast wind event, near-bed currents and sediment transport on the shoal follow the wind direction toward the southwest, leading to sand transport from the northern face to the crest and silt transport in an along-shoal direction. Within the channel, transport is dominated by suspended silt transport in the upwind direction. During the southwest wind event, nearbed currents and sediment transport on the shoal again follow the wind, to the northeast, leading to sand and silt transport from the crest to the northern face; silt transport in the channel again opposes the wind direction. At the southern shoal (Fig. 10), the entire simulation and the northeast wind event simulation indicate sand transport from the northern face to the crest of the shoal, while silt is winnowed from the shoal. During the southwest wind event, sand and silt are mostly eroded from the crest of the shoal and deposited on the downwind side. Silt transport in the channels again counters the wind direction, though in the southwest wind case channel fluxes are minimal. The simulations reinforce two key points: (1) along-wind currents, waves, and stresses on the shoal
Entire period

(1 Nov 2014 - 1 Mar 2015)



NE wind event

(7-9 Dec 2014)
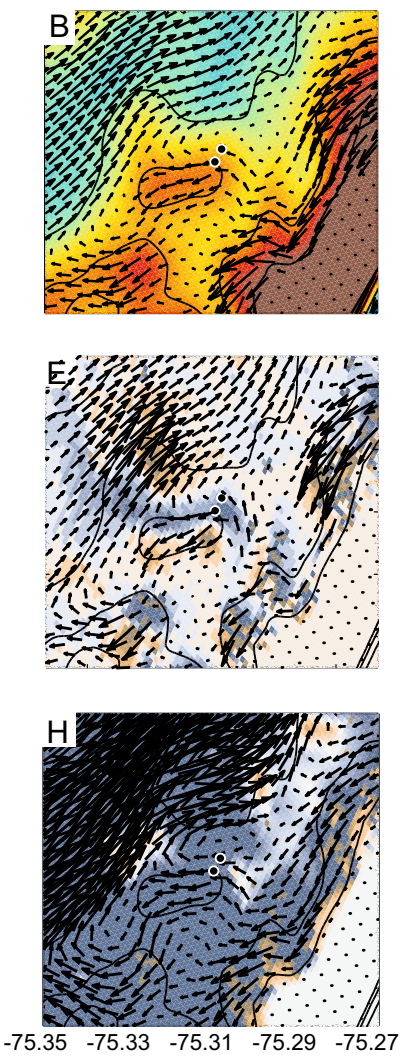

SW wind event (23-25 Nov 2014)
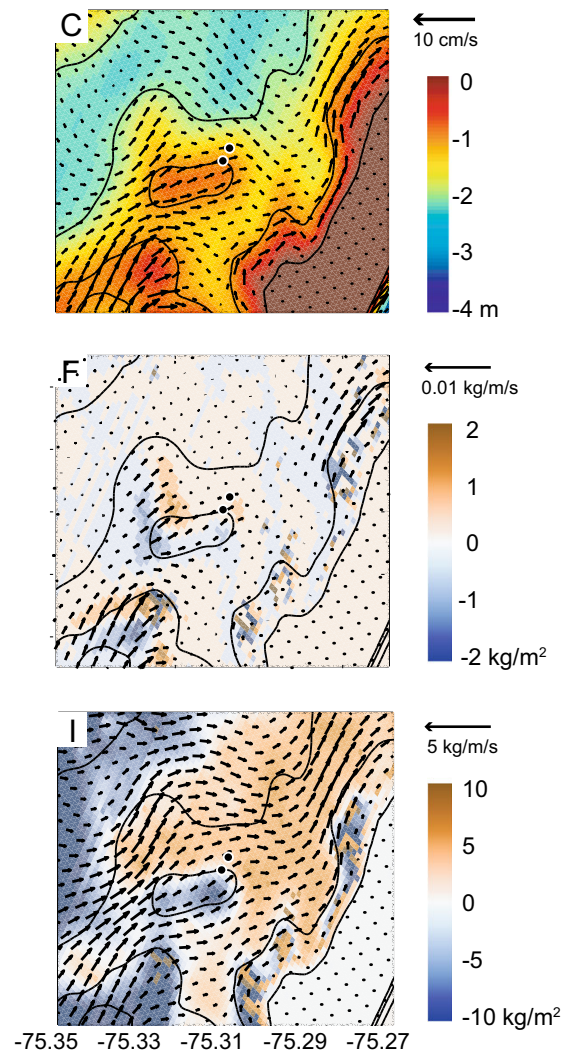

Fig. 10 Near-bed currents and bathymetry (panels a-c), combined suspended and bedload and bed mass change of sand class (panels $\mathbf{d}-\mathbf{f}$ ), and combined suspended and bedload and bed mass change of silt classes (panels $\mathbf{g - i}$ ), over the entire simulation $(\mathbf{a}, \mathbf{d}, \mathbf{g}), \mathrm{NE}$ wind event $(\mathbf{b}, \mathbf{e}, \mathbf{h})$, and SW wind event (c, f, i), at southern shoal site (sites CB04, CB05). Sites are shown with black dots. Bed mass change of $10 \mathrm{~kg} / \mathrm{m}^{2}$ corresponds to vertical change of $7.5 \mathrm{~mm}$ assuming density of $2650 \mathrm{~kg} /$ $\mathrm{m}^{3}$ and porosity of 0.5 
Entire period

(1 Nov 2014 - 1 Mar 2015)

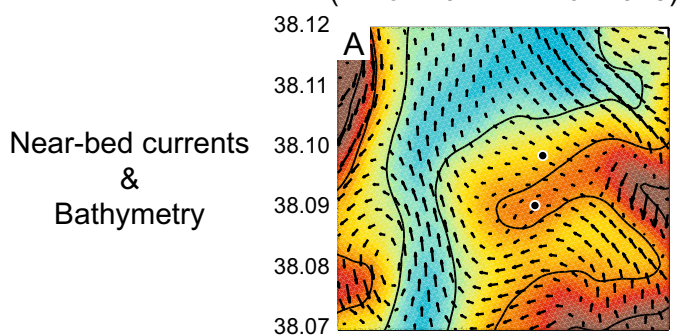

Sand transport \&

Bed mass change
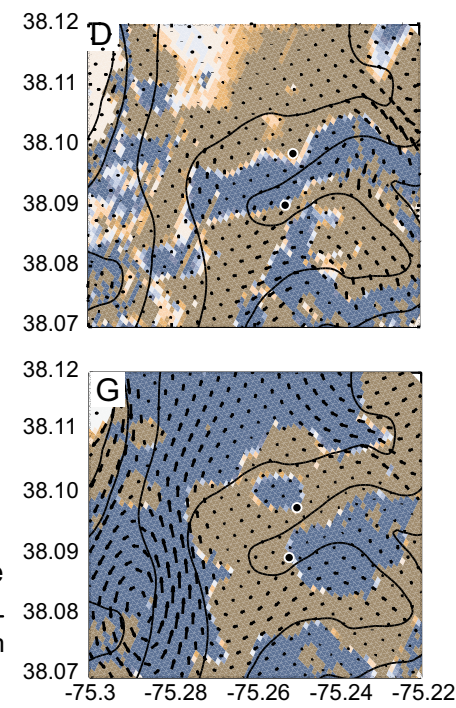

NE wind event

(7-9 Dec 2014)
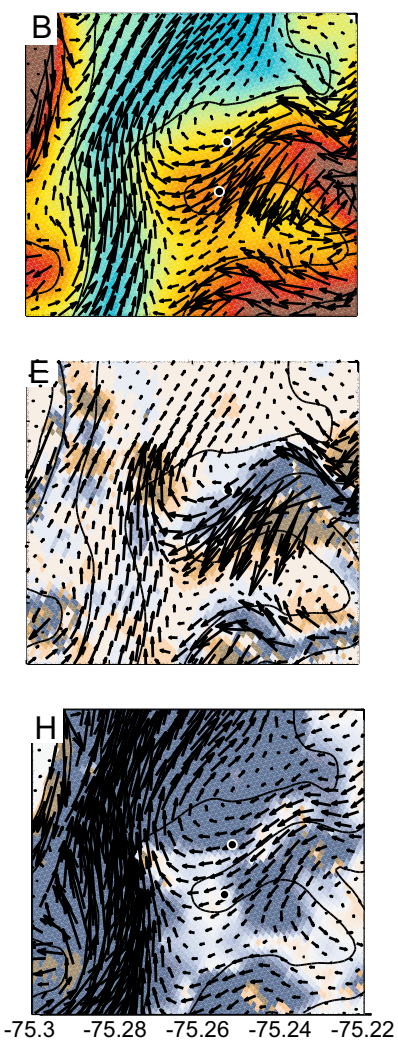

SW wind event (23-25 Nov 2014)
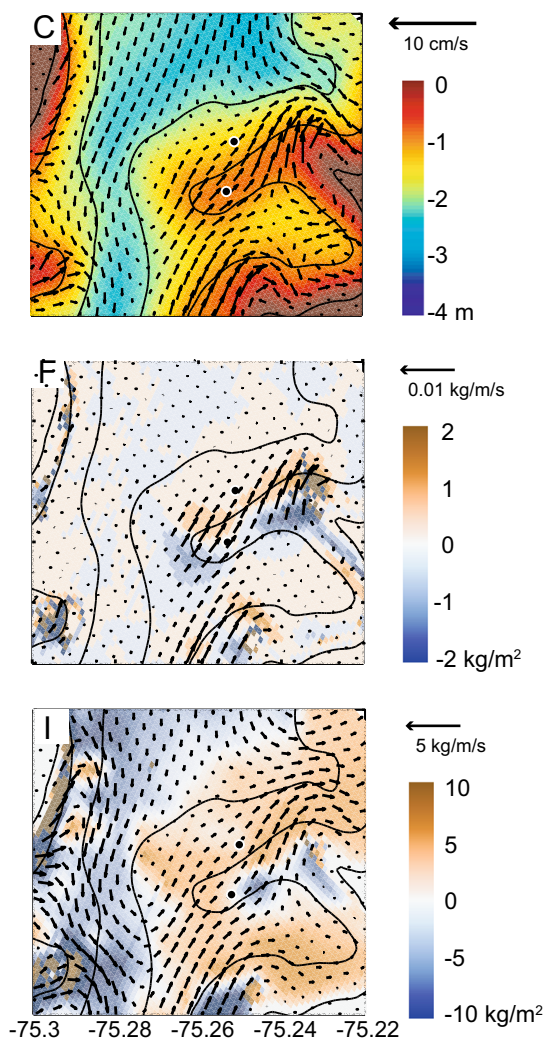

Fig. 11 Near-bed currents and bathymetry (panels a-c), combined suspended and bedload and bed mass change of sand class (panels $\mathbf{d}-\mathbf{f}$ ), and combined suspended and bedload and bed mass change of silt classes (panels $\mathbf{g}-\mathbf{i})$, over the entire simulation $(\mathbf{a}, \mathbf{d}, \mathbf{g}), \mathrm{NE}$ wind event $(\mathbf{b}, \mathbf{e}, \mathbf{h})$,

transport sand and silt as suspended load and bedload in the same direction as the wind, with opposing transport in the deeper channels, and (2) northeast events tend to and SW wind event (c, f, i), at northern shoal site (sites CB07, CB08). Sites are shown with black dots. Bed mass change of $10 \mathrm{~kg} / \mathrm{m}^{2}$ corresponds to vertical change of $7.5 \mathrm{~mm}$ assuming density of $2650 \mathrm{~kg}$ / $\mathrm{m}^{3}$ and porosity of 0.5

steepen the shoals and winnow fines while southwest events tend to flatten the shoals and deposit fines on the downwind side.
Fig. 12 Comparison of detrended observational seabed elevation data and de-trended numerical model results. Optimal site refers to model grid cell within $500 \mathrm{~m}$ of the observational site (see Fig. 1) with the highest skill score relative to observational data, to demonstrate spatial variability in skill. Gray bars indicate storm events shown in Figs. 12 and 13
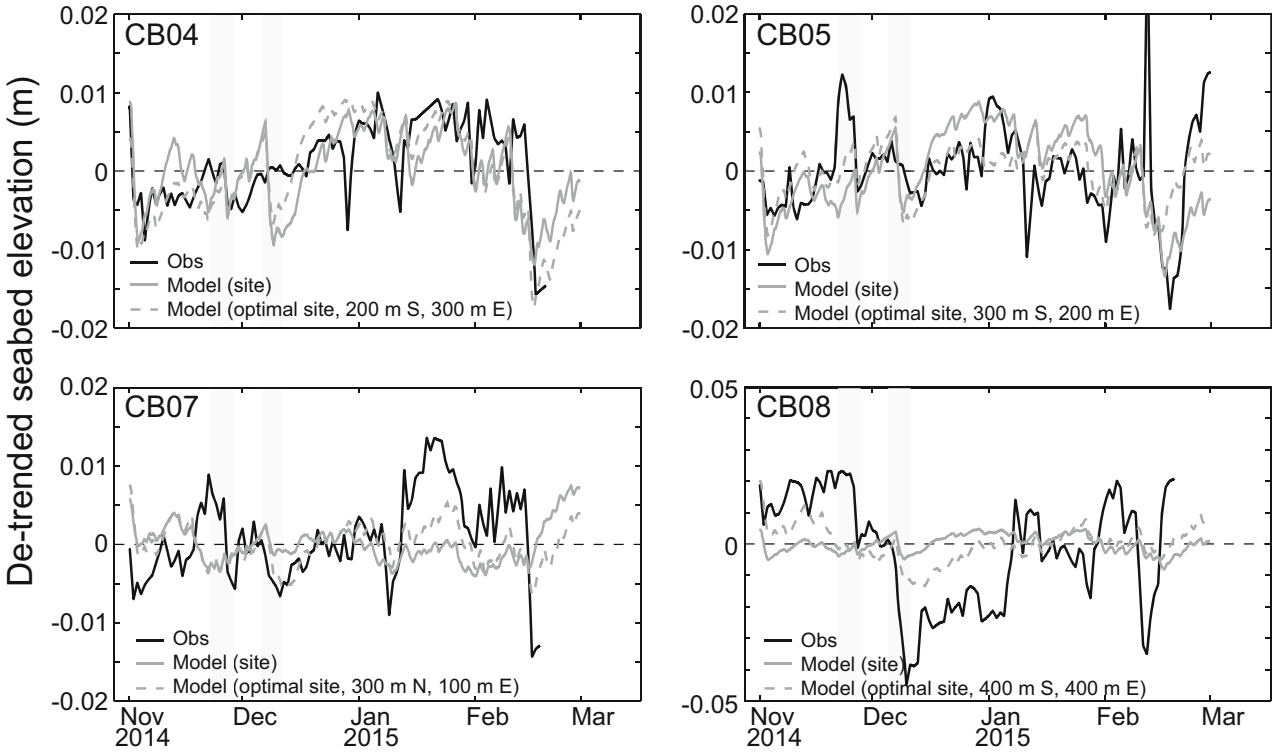


\section{Discussion}

\section{Timescales of Bathymetric Change in Back-Barrier Estuaries}

Back-barrier estuaries are characterized by gradients in sediment type for many reasons, including overwash processes, shoreline erosion, storm reworking, and sediment-vegetation feedbacks. The contrast between channel and shoal sediment transport processes, along with the wind-driven nature of transport, suggests a conceptual model of sediment transport in back-barrier estuaries based on cross-bay location and sediment source. Back-barrier shoals, formed by overwash or new inlets and dominated by sand, will exhibit net transport in the dominant wind direction (in terms of excess stress). The northern shoal occupied for this study appears to be a relict flood-tidal shoal from a historic inlet (Seminack and Buynevich 2009) and has likely evolved geomorphically since its initial formation. Deeper mud-dominated basins, supplied by mainland shoreline erosion or terrestrial input of fine sediment, will exhibit upwind transport in opposition to the dominant wind direction (Csanady 1973). Over decadal timescales, this pattern may be part of the long-term migration of barrier islands: sand supplied to the estuary during episodic events is preferentially transported in the same direction as the dominant winds and offshore sand, though the geomorphic change of the entire barrier is also controlled by external sediment supply and cross-shore transport from offshore.

One caveat to this conceptual model is the interaction of sediment transport with stabilizing vegetation. Marsh vegetation can rapidly colonize washover deposits of optimal thickness (Walters and Kirwan 2016) and can thereby prevent further transport. Submerged aquatic vegetation such as seagrass tends to reduce sediment transport once a canopy is established, creating a positive feedback loop of decreased resuspension, increased light penetration, and increased biomass (Hansen and Reidenbach 2013). On sand-dominated shoals, low turbidity and shallow depth facilitate seagrass colonization and initiation of the feedback loop. In fact, the positions of seagrass meadows in Chincoteague Bay have been relatively stable over the last few decades (VIMS 2016; Fig. 13). Interannual variability in seagrass coverage is large, but the positions of the meadows, specifically on the two shoals studied here, appear constant. One possible explanation is that initial formation of the shoals (due to overwash or inlet dynamics) was followed by gradual migration due to wind forcing, until seagrass was able to colonize the shoal. At that point, the crest of the shoal was stabilized, preventing net movement of the shoal on annual timescales. It is important to note that seasonal changes in seagrass biomass could alter this pattern, with enhanced transport in winter/spring and minimal transport in summer/fall (Ganthy et al. 2013). It is possible that reemergence of seagrass in the spring is responsible for the relatively stable bathymetry at sites $\mathrm{CB} 05$ and CB08 during the latter portion of the deployment. However, as sea level rises, barrier island migration and estuarine processes will be modified and the complex interplay between hydrodynamics, sediment transport, light penetration, and vegetation may lead to migration of seagrass meadows or complete loss as suitable habitat shifts landward (Dolch and Reise 2010; del Barrio et al. 2014).

\section{Resolving Storm-Induced Bathymetric Changes and Processes with Models}

Given the difficulty of resolving bathymetric changes in estuaries with observations, models have a fundamental role in elucidating mechanisms of estuarine geomorphic processes. It is therefore important to identify the shortcomings of models in this role. Even in the present study, with wellresolved grain size and hydrodynamic data to parameterize the model, we can only achieve meager skill at resolving annual and episodic changes. This is partially due to cascading errors: we can reliably simulate water levels $(\mathrm{BSS}=0.56$ at site $\mathrm{CB} 07$ ), and to a lesser extent wave-current stresses (BSS $=0.34$ at site $\mathrm{CB} 07$ ), but modeling the ensuing bed change is substantially more difficult. The uncertainties in sediment transport formulations, specifying bed composition, and sediment matrix effects are large and not easily overcome. Ostensibly, model "over-tuning" could lead to a more accurate simulation of bed change, but it would not further our fundamental understanding of the bathymetric response to storm forcing.

There are complex factors that we are not yet able to completely account for in the model, including wave skewness (Green and MacDonald 2001), feedbacks between vegetation and sediment transport (Ganthy et al. 2013), the erodibility of sand-clay mixtures (Mitchener and Torfs 1996), influence of benthic microalgae and extracellular polymer substances (Malarkey et al. 2015), and fine-scale vertical gradients in sediment composition. In the present study, we selected sites that appeared exposed to the dominant external forcing, and both the observations and model support a shoal-wide geomorphic response to the forcing. However, in areas with more complex morphology, the models will fall short. For example, the pre/post-Hurricane Sandy LiDAR-derived bathymetric change from Barnegat Bay, New Jersey (Wright et al. 2014a, b) resolved bathymetric changes near the southern inlet when flight lines of the airborne system overlapped (Fig. 14). However, the model of Barnegat Bay described by Defne and Ganju (2015), which adequately resolved hydrodynamics and residence time with horizontal resolution $\sim 50 \mathrm{~m}$ in the same location, does not have the resolution to capture these storm-induced changes. Conversely, hydrodynamic models of this resolution have 

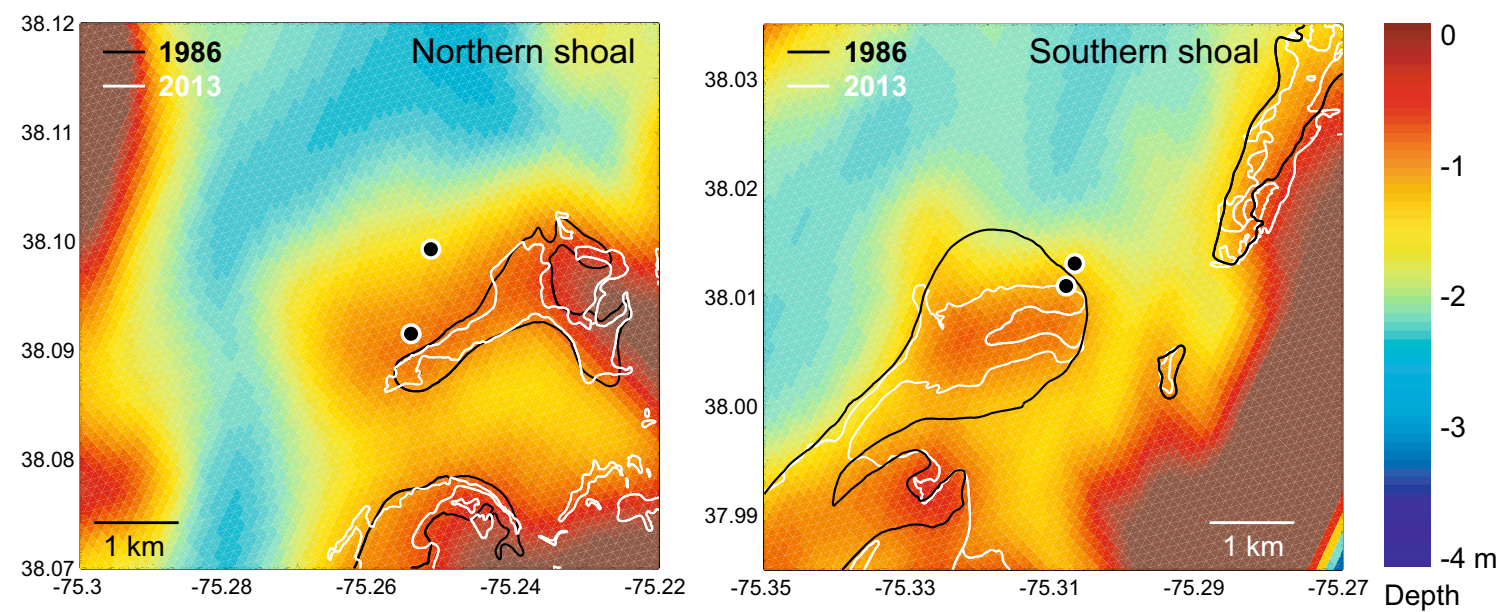

Fig. 13 Historical seagrass presence/absence delineation (VIMS 2016) from northern and southern shoals. While coverage has changed over the 25-year period, position of the beds appears unchanged

been shown to capture longer-term signals of bathymetric change in other systems impacted by large external forcing change (Ganju et al. 2009; van der Wegen et al. 2011). Ultimately, the limitations of observations and models must lead to a revision of expectations for evaluating storm-induced bathymetric change. It is unreasonable to expect broad-scale mapping techniques such as LiDAR or swath bathymetry to capture changes $<10 \mathrm{~cm}$; point methods such as altimetry can resolve these changes, though large arrays would be needed to cover, for example, a channel-shoal transect. At the same time, we cannot expect even well-developed numerical models to reproduce fine-scale details and processes given parameter uncertainty and model resolution.

\section{Estuarine Resilience to Storms from a Sediment Transport Perspective}

Recent storm events have highlighted the need to quantify the current and future resilience (i.e., ability to return to a
Fig. 14 LiDAR-derived bathymetric change from pre- and post-Hurricane Sandy airborne surveys in southern Barnegat Bay. Grid lines are from the hydrodynamic model of Defne and Ganju (2015), with an approximate horizontal resolution of $50 \mathrm{~m}$ in this region

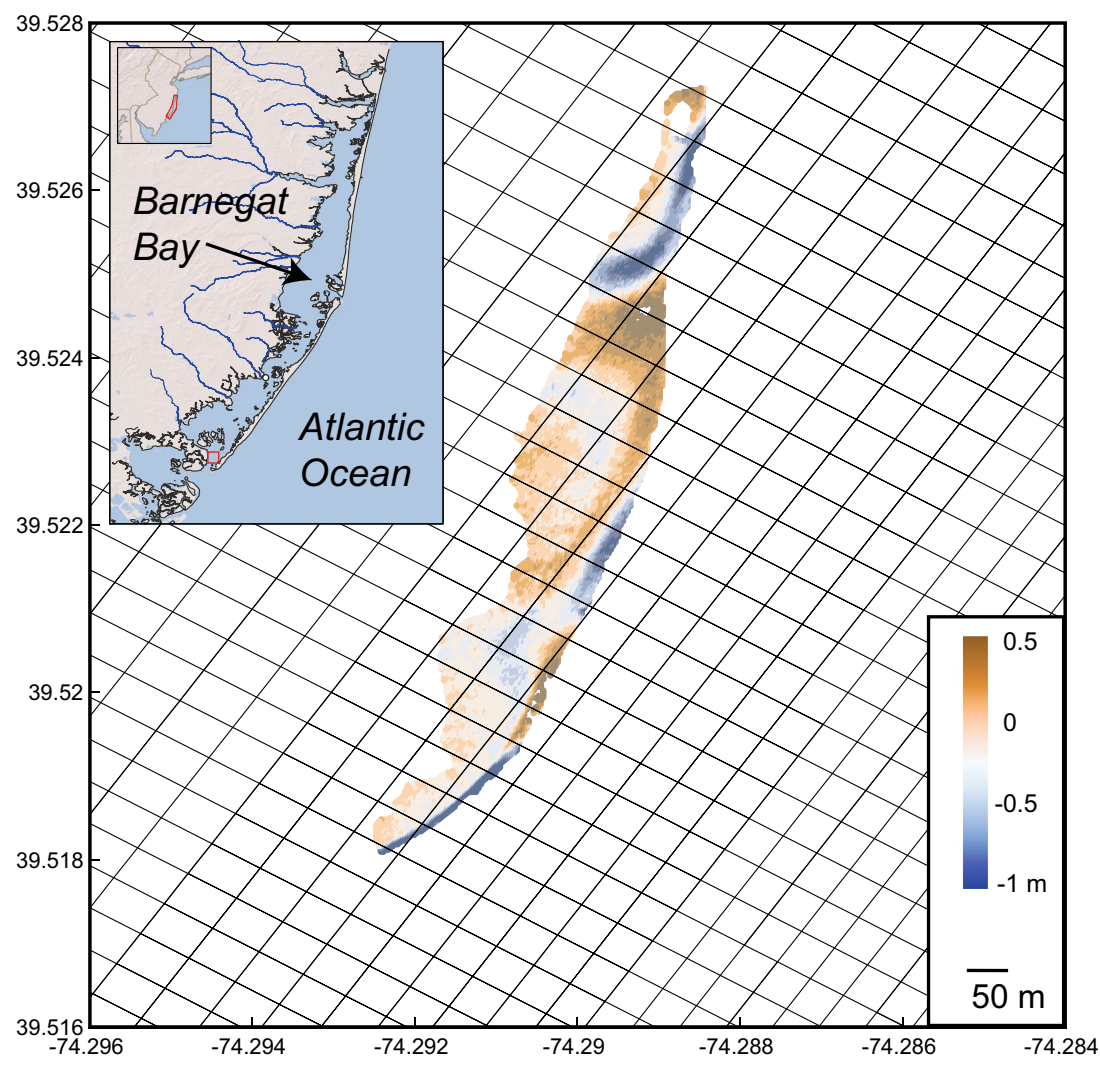


functional state after a disturbance) of natural features and ecosystems. In an idealized sense, the resilience of barrier-island/estuary systems (including the mainland shoreline) could be defined by the ability of these environments to naturally evolve in search of a quasi-equilibrium state. Though morphologic evolution occurs over long timescales (centuries to millennia), it can be thought of as the cumulative effect of episodic sediment transport events that alter the positions of the barrier island and the mainland shoreline. Storms erode and transport sediment from the barrier and into the estuary, moving both sides of the barrier shoreline landward. Mainland shoreline position is controlled by wave erosion; erosion of the marsh platform releases sediment that is deposited on the fringing marsh edge, building up levee elevation as the marsh is forced landward (Reed 1988). From a geomorphic perspective, our data show that back-barrier estuaries appear to be relatively resilient to large storms, with small changes in depth that should not induce large changes in ecosystem function. This is supported by recent work in Barnegat Bay, New Jersey, where the regional geomorphic response of the estuary to Hurricane Sandy was insignificant, except for localized changes near inlets and directly behind the barrier island (Miselis et al. 2015). Furthermore, our observations from Chincoteague Bay suggest that localized overwash and inlet-related deposits may be stabilized through a positive feedback between seasonal and interannual sediment transport and vegetation, further contributing to the resilience of the barrierisland/estuary system by maintaining shallow back-barrier depths and perhaps reducing the influence of wave erosion on the back-barrier shoreline (Fonseca and Cahalan 1992).

It is important to note that this conceptual model of barrier-island/estuary system resilience is relatively simple and does not account for alongshore variability in sediment fluxes or anthropogenic alterations of sediment exchange between barrier islands, estuaries, and the mainland. Significant alongshore variability in shoreline and dune elevation changes and estuarine accumulation resulting from Hurricane Sandy were observed in Barnegat Bay (Miselis et al. 2015); if the cumulative processes that result in transgression are not alongshore uniform, system resilience may not be uniform. The authors suggested several reasons for the alongshore variability, including sediment availability, island width, and, perhaps most importantly, human alterations to typical sediment transport pathways (Miselis et al. 2015). In Chincoteague Bay, however, where anthropogenic influence on the system is small, estuarine sediment transport processes may be responsible for "smoothing" back-barrier morphology and distributing sediment, enhancing system-wide resilience.

\section{Conclusion}

We quantified the bathymetric change in Chincoteague Bay, a shallow back-barrier estuary, over a 1 -year period, with a combination of acoustic sensors and numerical modeling. Strong wind events drove upwind near-bottom flows in the channels and downwind flows on the shoals, in accordance with the expected wind-driven response. During these events, the maximum bathymetric change from a single storm event was less than $5 \mathrm{~cm}$ on a sand-dominated shoal. This indicates that attempting to resolve storm-induced bathymetric change using swath bathymetry or airborne LiDAR is likely impossible in systems such as this due to change detection errors exceeding $20 \mathrm{~cm}$. The point observations and modeling from this study show that the windward side of the shoals steepen in response to northeast wind forcing during the fall and winter and flatten when impacted by southwest winds. Fine sediment transport in the channel should follow a converse pattern, with northeast sediment flux in the fall and winter and southwest sediment flux in the spring and summer. These sediment transport patterns have ramifications for the geomorphic and ecological trajectory of back-barrier lagoons over annual and decadal timescales. For example, the balance between seagrass colonization, bed stabilization, sediment resuspension, and light attenuation is likely controlled by the phasing of wind events with seasonal changes in seagrass biomass. The storminduced response of sediment transport on seagrass-colonized shoals and suspended sediment in the channels will modulate ecological habitat from a depth and light perspective.

Acknowledgments We thank Sandra Brosnahan, Dave Loewensteiner, Nick Nidzieko, Ellyn Montgomery, and Pat Dickhudt for field and data assistance. Bruce Jaffe and two anonymous reviewers provided constructive feedback on the manuscript. This study was part of the Estuarine Physical Response to Storms project (GS2-2D), supported by the Department of the Interior Hurricane Sandy Recovery program. Timeseries data can be accessed at the USGS Oceanographic Time-Series Database at http://dx.doi.org/10.5066/F7DF6PBV. Model metadata and output can be accessed via a number of common protocols at http://geoport.whoi.edu/thredds/catalog/clay/usgs/users/ nganju/chincoteague_bedelevation/catalog.html. Any use of brand names is for descriptive purposes only and does not constitute endorsement by the US Government.

Open Access This article is distributed under the terms of the Creative Commons Attribution 4.0 International License (http:// creativecommons.org/licenses/by/4.0/), which permits unrestricted use, distribution, and reproduction in any medium, provided you give appropriate credit to the original author(s) and the source, provide a link to the Creative Commons license, and indicate if changes were made.

\section{References}

Ariathurai, C.R., and K. Arulanandan. 1978. Erosion rates of cohesive soils. Journal of the Hydraulics Division 104: 279-282. 
Bailly, J., Y.L. Coarer, P. Languille, C. Stigermark, and T. Allouis. 2010. Geostatistical estimations of bathymetric LiDAR errors on rivers. Earth Surface Processes and Landforms 35: 1199-1210.

Bartberger, C.E. 1976. Sediment sources and sedimentation rates, Chincoteague Bay, Maryland and Virginia. Journal of Sedimentary Research, 46: 326-336.

Bassoullet, P., P. Le Hir, D. Gouleau, and S. Robert. 2000. Sediment transport over an intertidal mudflat: field investigations and estimation of fluxes within the "Baie de Marenngres-Oleron"(France). Continental Shelf Research 20: 1635-1653.

Brier, G.W. 1950. Verification of forecasts expressed in terms of probability. Monthly Weather Review 78: 1-3.

Chubarenko, I., and I. Tchepikova. 2001. Modelling of man-made contribution to salinity increase into the Vistula Lagoon (Baltic Sea). Ecological Modelling 138: 87-100.

Csanady, G.T. 1973. Wind-induced barotropic motions in long lakes. Journal of Physical Oceanography 3: 429-438.

Defne, Z. and Ganju, N.K. 2015. Quantifying the residence time and flushing characteristics of a shallow, back-barrier estuary: application of hydrodynamic and particle tracking models. Estuaries and Coasts, 38(5): 1719-1734.

del Barrio, P., N.K. Ganju, A.L. Aretxabaleta, M. Hayn, A. García, and R.W. Howarth. 2014. Modeling future scenarios of light attenuation and potential seagrass success in a eutrophic estuary. Estuarine, Coastal and Shelf Science 149: 13-23.

Dillow, J.J. and E.A. Greene. 1999. Ground-water discharge and nitrate loadings to the coastal bays of Maryland. Water Resources Investigation Report 99-4167, US Department of the Interior, US Geological Survey.

Dolch, T., and K. Reise. 2010. Long-term displacement of intertidal seagrass and mussel beds by expanding large sandy bedforms in the northern Wadden Sea. Journal of Sea Research 63: 93-101.

Dusek, G. 2011. Daily to yearly variations in rip activity over kilometer scales. Department of Marine Sciences. Chapel Hill, North Carolina: University of North Carolina at Chapel Hill, Ph.D. dissertation, $200 \mathrm{p}$.

Fonseca, M.S., and J.A. Cahalan. 1992. A preliminary evaluation of wave attenuation by four species of seagrass. Estuarine, Coastal and Shelf Science 35: 565-576.

Ganju, N.K., M.J. Brush, B. Rashleigh, A.L. Aretxabaleta, P. del Barrio, J.S. Grear, L.A. Harris, S.J. Lake, G. McCardell, J. O’Donnell, D.K Ralston, R.P. Signell, J.M. Testa, and J.M. Vaudrey. 2015. Progress and challenges in coupled hydrodynamic-ecological estuarine modeling. Estuaries and Coasts 39: 311-332.

Ganju, N.K., D.H. Schoellhamer, and B.E. Jaffe. 2009. Hindcasting of decadal-timescale estuarine bathymetric change with a tidaltimescale model. Journal of Geophysical Research: Earth Surface 114: F04019.

Ganthy, F., A. Sottolichio, and R. Verney. 2013. Seasonal modification of tidal flat sediment dynamics by seagrass meadows of Zostera noltii (Bassin d'Arcachon, France). Journal of Marine Systems 109: S233-S240.

Green, M.O., and I.T. MacDonald. 2001. Processes driving estuary infilling by marine sands on an embayed coast. Marine Geology 178(1): 11-37.

Hansen, J.C., and M.A. Reidenbach. 2013. Seasonal growth and senescence of a Zostera marina seagrass meadow alters wave-dominated flow and sediment suspension within a coastal bay. Estuaries and Coasts 36: 1099-1114.

Harris, C.K., and P.L. Wiberg. 1997. Approaches to quantifying longterm continental shelf sediment transport with an example from the Northern California STRESS mid-shelf site. Continental Shelf Research 17: 1389-1418.

Hilldale, R.C., and D. Raff. 2008. Assessing the ability of airborne LiDAR to map river bathymetry. Earth Surface Processes and Landforms 33: 773-783.
Jaffe, B.E., R.E. Smith, and A.C. Foxgrover. 2007. Anthropogenic influence on sedimentation and intertidal mudflat change in San Pablo Bay, California 1856-1983. Estuarine, Coastal and Shelf Science 73: $175-187$.

Jestin, H., Bassoullet, P., Le Hir, P., L'Yavanc, J. and Y. Degres. 1998. Development of ALTUS, a high frequency acoustic submersible recording altimeter to accurately monitor bed elevation and quantify deposition or erosion of sediments. In: OCEANS'98 Conference Proceedings, 1: 189-194.

Johnson, D. 2002. DIWASP version 1.1, a directional wave spectra toolbox for MATLAB®: User manual. Centre for Water Research, University of Western Australia.

Jones, N.L., and S.G. Monismith. 2007. Measuring short-period wind waves in a tidally forced environment with a subsurface pressure gauge. Limnology and Oceanography: Methods 5: 317-327.

Lopez, C.B., J.E. Cloern, T.S. Schraga, A.J. Little, L.V. Lucas, J.K. Thompson, and J.R. Burau. 2006. Ecological values of shallowwater habitats: Implications for the restoration of disturbed ecosystems. Ecosystems 9: 422-440.

Madsen, O.S. 1994. Spectral wave-current bottom boundary layer flows. In: Proc. of the 24th International Conference Coastal Engineering Research Council, Kobe Japan, 15 p.

Malarkey, J., J.H. Baas, J.A. Hope, R.J. Aspden, D.R. Parsons, J. Peakall, D.M. Paterson, R.J. Schindler, L. Ye, I.D. Lichtman, and S.J. Bass 2015. The pervasive role of biological cohesion in bedform development. Nature Communications 6: 6257.

Miselis, J.L., B.D. Andrews, R.S. Nicholson, Z. Defne, N.K. Ganju, and A. Navoy. 2015. Evolution of mid-Atlantic coastal and back-barrier estuary environments in response to a hurricane: Implications for barrier-estuary connectivity. Estuaries and Coasts. doi:10.1007/s12237-015-0057-x.

Mitchener, H., and H. Torfs. 1996. Erosion of mud/sand mixtures. Coastal Engineering 29(1): 1-25.

Mukai, A.Y., Westerink, J.J., Luettich Jr., R.A., Mark, D. 2002. Eastcoast 2001, A tidal constituent database for Western North Atlantic, Gulf of Mexico and Caribbean Sea. U.S. Army Corps of Engineers Technical Report ERDC/CHL TR-02-24. 196 pp.

National Oceanic and Atmospheric Administration. 2016. The North American Mesoscale Forecast System, www.emc.ncep.noaa. gov/index.php?branch=NAM, accessed July 2016.

Olabarrieta, M., Warner, J.C. and N. Kumar. 2011. Wave-current interaction in Willapa Bay. Journal of Geophysical Research: Oceans 116(C12).

Pritchard, D.W. 1960. Salt balance and exchange rate for Chincoteague Bay. Chesapeake Science 1: 48-57.

Ralston, D.K., Geyer, W.R. and J.A. Lerczak. 2010. Structure, variability, and salt flux in a strongly forced salt wedge estuary. Journal of Geophysical Research: Oceans 115(C6).

Reed, D.J. 1988. Sediment dynamics and deposition in a retreating coastal salt marsh. Estuarine, Coastal and Shelf Science 26: 67-79.

Seminack, C.T., and I.V. Buynevich. 2013. Sedimentological and geophysical signatures of a relict tidal inlet complex along a wavedominated barrier: Assateague Island, Maryland, USA. Journal of Sedimentary Research 83(2): 132-144.

Soulsby, R., 1997. Dynamics of marine sands: a manual for practical applications. Thomas Telford.

Soulsby, R.L. and Damgaard, J.S., 2005. Bedload sediment transport in coastal waters. Coastal Engineering, 52(8): 673-689.

Suttles, S.E., Ganju, N.K., Brosnahan, S.M., Montgomery, E.T., Dickhudt, P.J., Borden, Jonathan, and Martini, M.A., 2016. Oceanographic and water-quality measurements in Chincoteague Bay, Maryland/Virginia, 2014-2015: U.S. Geological Survey data release, doi10.5066/F7DF6PBV.

Traykovski, P. 2007. Observations of wave orbital scale ripples and a nonequilibrium time-dependent model. Journal of Geophysical Research 112: C06026. doi:10.1029/2006JC003811. 
Traykovski, P., R. Geyer, and C. Sommerfield. 2004. Rapid sediment deposition and fine-scale strata formation in the Hudson estuary. Journal of Geophysical Research 109: F02004. doi:10.1029/2003 JF000096.

U.S. Army Corps of Engineers. 2013. 2012 Post-superstorm sandy lidar elevation data, USACE National Coastal Mapping Program, accessed October 1, 2014 at https://catalog.data.gov/dataset/2012post-superstorm-sandy-lidar-elevation-data-usace-national-coastalmapping-program

U.S. Geological Survey. 2015. The national map, 3DEP products and services: The National Map, 3D Elevation Program Web page. Accessed October 1, 2014 at http://nationalmap.gov/3dep_ prodserv.html.

Van der Wal, D., and K. Pye. 2003. The use of historical bathymetric charts in a GIS to assess morphological change in estuaries. The Geographical Journal 169: 21-31.

Van der Wegen, M., B.E. Jaffe, and J.A. Roelvink. 2011. Process-based, morphodynamic hindcast of decadal deposition patterns in San Pablo Bay, California, 1856-1887. Journal of Geophysical Research: Earth Surface 116: F2.

Virginia Institute of Marine Science. 2016. SAV in Chesapeake Bay and Coastal Bays, http://web.vims.edu/bio/sav/gis_data.html, accessed February 11, 2016.

Walters, D.C., and M.L. Kirwan. 2016. Optimal hurricane overwash thickness for maximizing marsh resilience to sea level rise. Ecology and Evolution 6: 2948-2956.
Warner, J.C., B. Armstrong, R. He, and J.B. Zambon. 2010. Development of a coupled ocean-atmosphere-wave-sediment transport (COAWST) modeling system. Ocean Modelling 35: 230-244.

Warner, J.C., C.R. Sherwood, R.P. Signell, C.K. Harris, and H.G. Arango. 2008. Development of a three-dimensional, regional, coupled wave, current, and sediment-transport model. Computers \& Geosciences 34: 1284-1306.

Wells, D.V., Hill, J.M., Park, M.J., and C.P. Williams. 1998. The shallow sediments of the Middle Chincoteague Bay Area in Maryland: physical and chemical characteristics. (Coastal and Estuarine Geology File Report No. 98-1): Maryland Geological Survey, Baltimore, MD., 104 pp.

Wells, D.V., Ortt, R.A., VanRyswick, S., Conkwright, R.D., and K.A. Offerman. 2004. Bathymetric survey of the Maryland portion of Chincoteague Bay, Coastal and Estuarine Geology File Report 04 04, Maryland Geological Survey.

Wells, D.V., S.M. Harris, J.M. Hill, J. Park, and C.P. Williams. 1997. The shallow sediments of upper Chincoteague Bay area in Maryland: Physical and chemical characteristics. Maryland Geological Survey Coastal and Estuarine Geology File Report No. 97-2.

Wright, C.W., Troche, R.J., Klipp, E.S., Kranenburg, C.J., Fredericks, A.M. and Nagle, D.B., 2014a. EAARL-B submerged topography: Barnegat Bay, New Jersey, pre-Hurricane Sandy, 2012 (No. 885). US Geological Survey.

Wright, C.W., Troche, R.J., Kranenburg, C.J., Klipp, E.S., Fredericks, X. and Nagle, D.B., 2014b. EAARL-B submerged topography: Barnegat Bay, New Jersey, post-Hurricane Sandy, 2012-2013 (No. 887). US Geological Survey. 